\title{
PENERAPAN PROFILE MATCHING DALAM MENGANALISA LAPORAN KEUANGAN PERUSAHAAN BATU BARA YANG TERDAFTAR DI BURSA EFEK INDONESIA
}

\author{
Annafi’ Franz ${ }^{1}$,Emil Riza Putra ${ }^{2}$ \\ Software Engineering Technology, \\ State Agricultural Polythechnic of Samarinda \\ J1. Samratulangi Samarinda 75131 \\ 1annafifranz@gmail.com \\ ²emilriza92@gmail.com
}

\begin{abstract}
Financial statements are an important instrument that is the duty of every company to publish them every year. The issuance of financial statements is useful for knowing the company's financial position. Especially companies that have gone public financial reports must be published publicly as a form of financial transparency to stakeholders. The issuance of these financial statements is useful for investors as consideration for investing in shares or withdrawing their shares in certain companies. Analyzing financial statements in general is done by ratio analysis, which is by looking at the company's financial ratios. But by adding the analysis method will enrich the results of the analysis of the company's financial statements. The addition of the analytical method is done by the profile matching method, which is to measure the ability of the company's financial ratios and rank them according to the company that has the best results.
\end{abstract}

Keywords: Company, Finance, Investor, Profile Matching.

\section{PENDAHULUAN}

\section{Latar Belakang}

Perkembangan teknologi informasi yang semakin pesat dewasa ini, maka sangat memungkinkan bagi suatu organisasi, perusahaan, instansi pemerintah ataupun perorangan untuk menggunakan dan menerapkan hasil dari teknologi tersebut. Salah satu hasil dari teknologi informasi tersebut bisa digunakan untuk memperoleh knowledge yang diperlukan sebagai bahan dalam pengambilan keputusan. Bahan tersebut bisa berbentuk data, di mana data yang terkumpul akan semakin banyak seiring dengan waktu operasi organisasi atau instansi pemerintah tersebut. Salah satunya adalah Bursa Efek Indonesia yang merupaka pasar modal terbesar di Indonesia, dan telah memiliki cabang di kota-kota besar di Indonesia. Perusahaan yang terdaftar di bursa efek wajib mempublikasikan laporan keuangannya setiap triwulan per 
tahun di website resmi Bursa Efek Indonesia, sebagai bentuk transparansi terhadap para pemegang saham. Investor akan menggunakan laporan tersebut sebagai bahan pertimbangan untuk membeli, menjual atau mempertahankan saham perusahaan tersebut.

Dalam melakukan proses penanaman modal melalui kegiatan jual beli saham yang ditawarkan oleh perusahaan, seorang investor akan mengharapkan adanya suatu tingkat pengembalian atas saham yang dibelinya. Tingkat pengembalian dapat diperoleh melalui pembagian deviden dan capital gain yaitu selisih dari harga sewaktu membeli dan menjual saham (Babalola and Abiola, 2013). Melalui analisis laporan keuangan seorang analis akan lebih memahami dan menafsirkan baik informasi keuangan kualitatif dan kuantitatif sehingga kesimpulan terpercaya ditarik tentang prospek perusahaan dan risiko (Natali et al). Analisa laporan keuangan umum menggunakan analisis rasio keuangan sebagai tolak ukur keadaan keuangan perusahaan. Setelah rasio keungan didapatkan, biasanya investor akan menilai rasio tersebut hanya pada perusahaan yang ditelitinya. Setelah dilakukan analisis rasio pada beberapa perusahaan, hasil tersebut dapat diolah kembali menggunakan Sistem
Pendukung Keputusan. Sistem pendukung keputusan merupakan bagian tak terpisahkan dari totalitas sistem organisasi keseluruhan. Suatu sistem organisasi mencakup sistem fisik, sistem keputusan dan sistem informasi (Eniyati, 2011).

Metode profile matching adalah salah satu metode dalam Sistem Pendukung Keputusan yang banyak digunakan. Penggunaan metode profile matching dengan membandingkan hasil rasio keuangan dengan standar industri. Dimana selisih antara hasil rasio tersebut dijadikan dasar perhitungan untuk membandingkan perusahaan yang diteliti. Setelah dilakukan proses membandingkan hasil rasio perusahaan di bursa efek Indonesia, akan didapatkan hasil berupa rangking perusahaan yang merupakan pilihan terbaik untuk berinvestasi.

\section{Rumusan Masalah}

1. Bagaimana menganalisa laporan keuangan perusahaan batubara yang terdaftar di Bursa Efek Indonesia tahun 2016-2018 dengan menggunakan analisis rasio?

2. Bagaimana menganalisa hasil analisis rasio perusahaan batubara yang terdaftar di Bursa Efek Indonesia tahun 2016-2018 dengan menggunakan metode profile 
matching?

\section{Tujuan Penelitian}

1. Untuk menganalisa laporan keuangan perusahaan batubara yang terdaftar di Bursa Efek Indonesia tahun 20162018 dengan menggunakan analisis rasio

2. Untuk menganalisa hasil analisis rasio perusahaan batubara yang terdaftar di Bursa Efek Indonesia tahun 20162018 dengan menggunakan metode profile matching

\section{KERANGKA TEORITIS}

\section{Penelitian Terdahulu}

Berikut ini dipaparkan beberapa penelitian terkait seputar metode Profile Matching dan Analisis Rasio:

1. Putra (2017), Penerapan metode profile matching dalam menganalisa laporan keuangan perusahaan sektor makanan dan minuman yang terdaftar di Bursa Efek Indonesia, Pada penelitian ini digunakan metode profile matching dan analisis rasio sebagai bahan pengambilan keputusan. Rasio yang digunakan adalah rasio aktivitas, liquiditas, solvabilitas dan profitabilitas.

2. Putra (2016), Penerapan algoritma rough set dan metode analisis rasio dalam menganalisa laporan keuangan (studi kasus Bursa Efek Indonesia cabang UPI-YPTK), Pada penelitian ini digunakan metode rough set dan analisis rasio sebagai bahan pengambilan keputusan. Rasio yang digunakan adalah rasio aktivitas, liquiditas, solvabilitas dan profitabilitas.

3. Seradi (2016), Penerapan metode profile matching untuk menentukan kelayakan pemberian kredit pada PNPM mandiri kota Banjarmasin, Pada penelitian ini digunakan metode profile matching untuk menentukan kelayakan pemberian kredit PNPM mandiri dengan kriteria kriteria yang telah ditetapkan pemetintah.

4. Irawan (2016), Penerapan profile matching untuk pencarian siswa SMP penerima beasiswa miskin dan berprestasi. Pada penelitian ini menggunakan metode profile matching untuk mencari siswa SMP yang berhak menerima beasiswa dengan penilaian kemampuan akademis dan kemampuan ekonomi.

5. Dewi (2013), Analisis laporan keuangan untuk menilai kinerja keuangan pada PT. Bank Rakyat Indonesia (PERSERO) Tbk. Pada penelitian ini menggunakan metode analisis rasio untuk menentukan kinerja keuangan PT. Bank Rakyat Indonesia (PERSERO) Tbk dengan menggunakan rasio aktivitas, 
liquiditas, solvabilitas dan profitabilitas.

\section{Teori Laporan Keuangan}

\section{Pengertian}

Pengertian laporan keuangan menurut Standar Akuntansi Keuangan (2018): Laporan keuangan adalah bagian dari proses pelaporan keuangan yang lengkap biasanya meliputi neraca, laporan laba rugi, laporan perubahan posisi keuangan yang dapat disajikan dalam berbagai cara seperti, misalnya : sebagai laporan arus kas, atau laporan arus dana, catatan dan laporan lain serta materi penjelasan yang merupakan bagian integral ari laporan keuangan. Di samping itu juga ternasuk skedul dan informasi tambahan yang berkaitan dengan laporan tersebut, misal : informasi keuangan segmen industri dan geografis serta pengungkapan pengaruh perubahan harga.

Laporan keuangan adalah hasil dari proses akuntansi dan merupakan informasi histories. Akuntansi adalah proses pengidentifikasian, mengukur dan melaporkan informasi ekonomi untuk membuat pertimbangan dan mengambil keputusan yang tepat bagi pemakai informsi tersebut (Kashmir, 2010)

Laporan keuangan merupakan komoditi yang bermanfaat dan dibutuhkan masyarakat, karena ia dapat memberikan informasi yang dibutuhkan pemakainya dalam dunia bisnis yang dapat menghasilkan keuntungan. Laporan kuangan disajikan kepda banyak pihak yang berkepentingan termasuk manajemen, kreditur, pemerintah dan pihak-pihak lainnya. Pemakai laporan keuangan meliputi investor sekarang dan investor potensial, karyawan, pemberi pinjaman, pemasok dan kreditur usaha lainnya, pelanggan, pemerintah serta lembaga-lembaganya, dan masyarakat.

Menurut Munawir (2010), analisis laporan keuangan adalah analisis laporan keuangan yang terdiri dari penelaahan atau mempelajari daripada hubungan dan tendensi atau kecenderungan (trend) untuk menentukan posisi keuangan dan hasil operasi serta perkembangan perusahaan yang bersangkutan. Menurut Harahap (2009), analisis laporan keuangan berarti menguraikan akunakun laporan keuangan menjadi unit informasi yang lebih kecil dan melihat hubungannya yang bersifat signifikan atau yang mempunyai makna antara yang satu dengan yang lain baik antara data kuantitatif maupun data nonkuantitatif dengan tujuan untuk mengetahui kondisi keuangan lebih dalam yang sangat penting dalam proses menghasilkan keputusan yang tepat. 


\section{Sistem Pendukung Keputusan dengan Profile Matching}

Dalam proses profile matching secara garis besar merupakan proses membandingkan antara kompetensi individu ke dalam kompetensi jabatan sehingga dapat diketahui perbedaan kompetensinya (disebut juga gap), semakin kecil gap yang dihasilkan maka bobot nilainya semakin besar yang berarti memiliki peluang lebih besar untuk kandidat menempati posisi tersebut (Seradi, 2016).

Menurut Masitoh (2013), proses pencocokan dengan metode profile matching (GAP) secara garis besar merupakan proses membandingkan antara nilai data aktual dari sebuah barang elektronik yang akan dinilai dengan nilai sebuah barang elektronik yang diharapkan atau nilai sebuah barang yang ideal, sehingga dapat diketahui perbedaan kompetensinya (GAP), semakin kecil GAP yang dihasilkan maka bobot nilainya semakin besar yang berarti memiliki peluang lebih besar untuk direkomendasikan bagi konsumen atau sebagai pendukung konsumen. Proses perhitungan pencocokan profil terdiri dari pemetaan gap, penentuan bobot nilai gap, perhitungan core factor, secondary factor, perhitungan nilai total dan penentuan ranking.

\section{METODE PENELITIAN}

Metode pengumpulan data dalam penelitian ini dimaksudkan untuk memperoleh data yang relevan dan akurat dengan masalah yang dibahas. Metode pengumpulan data tersebut adalah :

1. Tinjauan Kepustakaan, metode ini dilakukan dengan mempelajari teoriteori dan konsep-konsep yang sehubungan dengan masalah yang diteliti penulis pada buku-buku, makalah, dan jurnal guna memperoleh landasan teoritis yang memadai untuk melakukan pembahasan.

2. Mengakses web dan situs-situs terkait, metode ini digunakan untuk mencari data-data atau informasi terkait pada website maupun situssitus yang menyediakan informasi sehubungan dengan masalah dalam penelitian ini.

Jenis data yang digunakan dalam penelitian ini adalah data kuantitatif, yaitu data yang diperoleh dalam bentuk angka-angka. Data kuantitatif dalam penelitian ini bersumber dari Laporan Keuangan perusahaan yang bergerak dibidang batubara yang dirilis resmi oleh website Bursa Efek Indonesia pada tahun 2016 - 2018. 
Sumber data yang digunakan dalam penelitian ini adalah data sekunder, yaitu data primer yang telah diolah oleh pihak lain atau data primer yang telah diolah lebih lanjut yang ada kaitannya dengan pembahasan dalam penelitian ini.

Dalam menganalisis laporan keuangan pada penelitian ini digunaan dua metode, yaitu analisis rasio dan profile matching. Langkah pertama ialah dengan menggunaan analisis rasio untuk mendapatkan rasio keuangan perusahaan yang diteliti. Setelah mendapatkan rasio perusahaan, kemudian diolah menggunakan profile matching. Profile matching digunakan untuk mengetahui peringkat perusahaan berdasarkan rasio keuangannya.

Penelitian ini menggunakan metode analisis rasio. Metode analisis yang digunakan dengan menganalisis laporan keuangan pada tahun (periode) tertentu, yaitu dengan membandingkan antara pos yang satu dan pos lainnya dalam laporan keuangan yang sama untuk tahun yang sama. Terdapat empat rasio keuangan yang dapat digunakan dalam menganalisis laporan keuangan perusahaan (Kasmir, 2010), yaitu :

1. Rasio Likuiditas
a. Rasio Lancar (RL1)
b. Rasio Cepat (RL2)
c. Rasio Kas (RL3)

2. Rasio Solvabilitas
a. Rasio Utang Terhadap Total Aktiva (RS1)
b. Rasio Utang Terhadap Ekuitas (RS2)
c. Long-Term Debt To Equity Ratio (RS3)

3. Rasio Aktivitas
a. Perputaran Piutang (RA1)
b. Perputaran Persediaan (RA2)
c. Perputaran Modal Kerja (RA3)

4. Rasio Profitabilitas
a. Net Profit Margin (RP1)
b. ROI (RP2)
c. $\mathrm{ROE}(\mathrm{RP} 3)$

Setelah mendapatkan hasil analisis rasio selanjutnya adalah dengan menggunakan profile matching, dengan tahapan sebagai berikut :

1. Pemetaan GAP

2. Perhitungan Bobot

3. Perhitungan $C F$ dan $S F$

4. Perhitungan Nilai Total

5. Perhitungan Nilai Rangking

\section{HASIL DAN PEMBAHASAN}

\section{Deskripsi Subjek Penelitian}

Penelitian ini bertujuan untuk mengungkap pengetahuan tersembunyi dari hasil rasio keuangan perusahaan. Penelitian ini meneliti perusahaan yang terdaftar di Bursa Efek Indonesia yang bergerak dibidang batu bara untuk laporan keuangan tahun 2016 - 2018 . 
Tabel 1. Deskripsi Subjek Penelitian

\begin{tabular}{clc}
\hline No & \multicolumn{1}{c}{ Nama Perusahaan } & Inisial \\
\hline $\mathbf{1}$ & ADARO ENERGY TBK & ADRO \\
$\mathbf{2}$ & BARA JAYA INTERNASIONALTBK & ATPK \\
$\mathbf{3}$ & MITRABARA ADIPERDANA TBK & MBAP \\
$\mathbf{4}$ & GOLDEN EAGLE ENERGY TBK & SMMT \\
$\mathbf{5}$ & TOBA BARA SEJAHTERA TBK & TOBA \\
$\mathbf{6}$ & SAMINDO RESOURCE TBK & MYOH \\
$\mathbf{7}$ & PERDANA KARYA PERKASA & PKPK \\
$\mathbf{8}$ & RESOURCE ALAM INDONESIA & KKGI \\
$\mathbf{9}$ & HARUM ENERGY & HRUM \\
$\mathbf{1 0}$ & GARDA TUJUH BUANA & GTBO \\
$\mathbf{1 1}$ & GOLDEN ENERGY MINES & GEMS \\
$\mathbf{1 2}$ & BUMI RESOURCE & BUMI \\
$\mathbf{1 3}$ & BAYAN RESOURCE & BYAN \\
$\mathbf{1 4}$ & DELTA DUNIA MAKMUR & DOID \\
$\mathbf{1 5}$ & ALFA ENERGI INVESTAMA & FIRE \\
$\mathbf{1 6}$ & TAMBANG BATUBARA BUKIT ASAM (PERSERO) & PTBA \\
$\mathbf{1 7}$ & PETROSEA & PTRO \\
$\mathbf{1 8}$ & ATLAS RESOURCES & ARII \\
\hline
\end{tabular}

(Sumber : sahamok.com 2019)

\section{Analisis Rasio}

Dalam menganalisa laporan keuangan dapat dilakukan dengan metode Analisis Rasio, data dikelompokkan berdasarkan rasio - rasio yang telah ditentukan. Pengelompokan data laporan keuangan berdasarkan keperluarn analisis rasio dikelompokkan menjadi tabel rekapitulasi laporan keuaungan. Hasil analisis rasio perusahaan batubara yang terdaftar di Bursa Efek Indonesia untuk tahun 2016 - 2018 sebagai berikut :

Tabel 2. Hasil Analisis Rasio

\begin{tabular}{|c|c|c|c|c|c|c|c|c|c|c|c|c|c|}
\hline \multirow{2}{*}{ Inisial } & \multirow{2}{*}{ Tahun } & \multicolumn{3}{|c|}{ Rasio Liquiditas } & \multicolumn{3}{|c|}{ Rasio Solvabilitas } & \multicolumn{3}{|c|}{ Rasio Aktifitas } & \multicolumn{3}{|c|}{ Rasio Profitabilitas } \\
\hline & & RL1 & RL2 & RL3 & RS1 & RS2 & RS3 & RA1 & RA2 & RA3 & RP1 & RP2 & RP3 \\
\hline \multirow{3}{*}{ ADRO } & 2016 & 2.47 & 2.36 & $167.08 \%$ & $41.95 \%$ & $72.28 \%$ & $55.25 \%$ & 8.39 & 34.38 & 1.58 & $0.36 \%$ & $0.14 \%$ & $0.24 \%$ \\
\hline & 2017 & 2.56 & 2.45 & $156.06 \%$ & $39.95 \%$ & $66.54 \%$ & $47.64 \%$ & 8.79 & 38.12 & 1.65 & $0.57 \%$ & $0.27 \%$ & $0.46 \%$ \\
\hline & 2018 & 1.96 & 1.82 & $113.65 \%$ & $39.06 \%$ & $64.10 \%$ & $45.13 \%$ & 11.50 & 32.32 & 2.26 & $0.65 \%$ & $0.33 \%$ & $0.55 \%$ \\
\hline \multirow{4}{*}{ ATPK } & 2016 & 0.69 & 0.47 & $0.17 \%$ & $53.52 \%$ & $115.13 \%$ & $83.85 \%$ & 0.10 & 0.20 & 0.06 & $-2713.38 \%$ & $-17.46 \%$ & $-37.55 \%$ \\
\hline & 2017 & 0.20 & 0.03 & $0.41 \%$ & $60.49 \%$ & $153.13 \%$ & $98.41 \%$ & 58.10 & 0.45 & 0.39 & $-1877.75 \%$ & $-31.22 \%$ & $-79.03 \%$ \\
\hline & 2018 & 0.25 & 0.11 & $0.22 \%$ & $69.46 \%$ & $227.40 \%$ & $147.12 \%$ & 2.22 & 1.35 & 0.77 & $-332.14 \%$ & $-15.75 \%$ & $-51.55 \%$ \\
\hline & 2016 & 3.41 & 2.97 & $183.26 \%$ & $21.26 \%$ & $27.01 \%$ & $2.78 \%$ & 7.55 & 19.11 & 2.47 & $19.31 \%$ & $31.06 \%$ & $39.45 \%$ \\
\hline \multirow[t]{3}{*}{ MBAP } & 2017 & 3.16 & 2.55 & $204.08 \%$ & $23.93 \%$ & $31.46 \%$ & $3.39 \%$ & 15.40 & 12.22 & 2.38 & $30.39 \%$ & $48.88 \%$ & $64.25 \%$ \\
\hline & 2018 & 2.64 & 2.08 & $132.71 \%$ & $28.43 \%$ & $39.72 \%$ & $6.80 \%$ & 8.84 & 11.31 & 2.39 & $26.10 \%$ & $38.83 \%$ & $54.25 \%$ \\
\hline & 2016 & 0.27 & 0.23 & $19.22 \%$ & $40.13 \%$ & $67.04 \%$ & $45.64 \%$ & 55.11 & 18.79 & 2.59 & $32.61 \%$ & $2.87 \%$ & $4.80 \%$ \\
\hline \multirow[t]{3}{*}{ SMMT } & 2017 & 0.48 & 0.46 & $14.44 \%$ & $36.82 \%$ & $58.27 \%$ & $35.31 \%$ & 7.39 & 21.58 & 1.00 & $69.53 \%$ & $4.82 \%$ & $7.62 \%$ \\
\hline & 2018 & 0.15 & 0.13 & $25.95 \%$ & $45.57 \%$ & $83.72 \%$ & $40.73 \%$ & 43.86 & 71.29 & 7.38 & $44.42 \%$ & $11.26 \%$ & $20.68 \%$ \\
\hline & 2016 & 0.97 & 0.75 & $51.55 \%$ & $43.52 \%$ & $77.05 \%$ & $27.66 \%$ & 20.24 & 16.50 & 3.66 & $5.65 \%$ & $5.58 \%$ & $9.87 \%$ \\
\hline \multirow[t]{3}{*}{ TOBA } & 2017 & 1.53 & 1.15 & $88.10 \%$ & $49.82 \%$ & $99.28 \%$ & $61.65 \%$ & 26.35 & 12.60 & 3.10 & $13.31 \%$ & $11.88 \%$ & $23.67 \%$ \\
\hline & 2018 & 1.22 & 0.79 & $49.49 \%$ & $57.04 \%$ & $132.76 \%$ & $78.98 \%$ & 22.05 & 8.81 & 3.09 & $15.53 \%$ & $13.57 \%$ & $31.58 \%$ \\
\hline & 2016 & 4.30 & 3.63 & $110.94 \%$ & $27.01 \%$ & $37.00 \%$ & $18.81 \%$ & 11.31 & 14.61 & 2.26 & $11.18 \%$ & $14.44 \%$ & $19.78 \%$ \\
\hline \multirow[t]{3}{*}{ МYOH } & 2017 & 2.85 & 2.30 & $69.16 \%$ & $24.64 \%$ & $32.70 \%$ & $3.23 \%$ & 12.21 & 11.38 & 2.19 & $6.54 \%$ & $9.04 \%$ & $12.00 \%$ \\
\hline & 2018 & 3.48 & 2.93 & $143.85 \%$ & $24.67 \%$ & $32.76 \%$ & $6.84 \%$ & 10.46 & 15.02 & 2.35 & $12.83 \%$ & $20.44 \%$ & $27.13 \%$ \\
\hline & 2016 & 0.71 & 0.53 & $2.15 \%$ & $55.75 \%$ & $125.98 \%$ & $1.44 \%$ & 1.07 & 0.55 & 0.14 & $162.70 \%$ & $8.67 \%$ & $19.59 \%$ \\
\hline \multirow[t]{3}{*}{ PKPK } & 2017 & 13.69 & 10.37 & $26.61 \%$ & $56.81 \%$ & $131.55 \%$ & $126.38 \%$ & 1.56 & 1.09 & 0.27 & $93.65 \%$ & $7.60 \%$ & $17.60 \%$ \\
\hline & 2018 & 111.31 & 87.16 & $425.31 \%$ & $56.54 \%$ & $130.11 \%$ & $129.52 \%$ & 1.17 & 0.86 & 0.19 & $55.89 \%$ & $2.99 \%$ & $6.89 \%$ \\
\hline & 2016 & 4.05 & 3.21 & $135.53 \%$ & $14.49 \%$ & $16.94 \%$ & $5.38 \%$ & 17.68 & 11.26 & 2.34 & $10.23 \%$ & $9.60 \%$ & $11.22 \%$ \\
\hline \multirow[t]{3}{*}{ KKGI } & 2017 & 3.54 & 3.06 & $158.58 \%$ & $15.64 \%$ & $18.54 \%$ & $5.73 \%$ & 15.86 & 15.31 & 2.08 & $16.05 \%$ & $12.79 \%$ & $15.17 \%$ \\
\hline & 2018 & 1.48 & 0.92 & $17.97 \%$ & $26.06 \%$ & $35.24 \%$ & $12.49 \%$ & 29.76 & 5.15 & 1.95 & $0.84 \%$ & $0.41 \%$ & $0.55 \%$ \\
\hline & 2016 & 5.07 & 4.91 & $436.44 \%$ & $14.02 \%$ & $16.30 \%$ & $1.41 \%$ & 10.55 & 26.92 & 0.81 & $8.28 \%$ & $4.35 \%$ & $5.06 \%$ \\
\hline \multirow[t]{2}{*}{ HRUM } & 2017 & 5.45 & 5.25 & $461.18 \%$ & $13.84 \%$ & $16.06 \%$ & $1.47 \%$ & 16.42 & 28.03 & 1.03 & $17.12 \%$ & $12.13 \%$ & $14.08 \%$ \\
\hline & 2018 & 4.56 & 4.04 & $317.58 \%$ & $16.99 \%$ & $20.46 \%$ & $2.92 \%$ & 11.47 & 9.55 & 1.08 & $11.94 \%$ & $8.59 \%$ & $10.35 \%$ \\
\hline GTBO & 2016 & 0.73 & 0.52 & $15.12 \%$ & $13.96 \%$ & $16.22 \%$ & $13.39 \%$ & - & 0.89 & 0.26 & $-2076.97 \%$ & $-9.46 \%$ & $-10.99 \%$ \\
\hline
\end{tabular}




\begin{tabular}{|c|c|c|c|c|c|c|c|c|c|c|c|c|c|}
\hline \multirow{2}{*}{ Inisial } & \multirow{2}{*}{ Tahun } & \multicolumn{3}{|c|}{ Rasio Liquiditas } & \multicolumn{3}{|c|}{ Rasio Solvabilitas } & \multicolumn{3}{|c|}{ Rasio Aktifitas } & \multicolumn{3}{|c|}{ Rasio Profitabilitas } \\
\hline & & RL1 & RL2 & RL3 & RS1 & RS2 & RS3 & RA1 & RA2 & RA3 & RP1 & RP2 & RP3 \\
\hline & 2017 & 0.58 & 0.12 & $3.36 \%$ & $20.20 \%$ & $25.31 \%$ & $13.16 \%$ & - & 3.57 & 2.80 & $0.36 \%$ & $0.06 \%$ & $0.07 \%$ \\
\hline & 2018 & 1.41 & 0.27 & $5.07 \%$ & $18.49 \%$ & $22.68 \%$ & $12.97 \%$ & $5,887.22$ & 6.44 & 5.23 & $6.85 \%$ & $3.99 \%$ & $4.89 \%$ \\
\hline & 2016 & 3.77 & 3.62 & $107.19 \%$ & $29.85 \%$ & $42.56 \%$ & $22.22 \%$ & 11.40 & 44.96 & 1.89 & $9.10 \%$ & $9.26 \%$ & $13.21 \%$ \\
\hline \multirow[t]{3}{*}{ GEMS } & 2017 & 1.68 & 1.62 & $71.00 \%$ & $50.51 \%$ & $102.06 \%$ & $17.69 \%$ & 22.89 & 47.58 & 1.83 & $15.81 \%$ & $20.34 \%$ & $41.10 \%$ \\
\hline & 2018 & 1.32 & 1.24 & $31.70 \%$ & $54.95 \%$ & $121.98 \%$ & $43.38 \%$ & 12.01 & 53.76 & 3.19 & $9.62 \%$ & $14.34 \%$ & $31.84 \%$ \\
\hline & 2016 & 0.69 & 0.68 & $0.38 \%$ & $189.77 \%$ & $-211.40 \%$ & $-183.95 \%$ & 0.05 & 1.79 & 0.04 & $514.52 \%$ & $3.88 \%$ & $-4.32 \%$ \\
\hline \multirow[t]{3}{*}{ BUMI } & 2017 & 0.57 & 0.55 & $3.11 \%$ & $92.25 \%$ & $1190.90 \%$ & $725.58 \%$ & 0.07 & 0.57 & 0.02 & $1397.77 \%$ & $6.57 \%$ & $84.77 \%$ \\
\hline & 2018 & 0.40 & 0.36 & $7.64 \%$ & $87.11 \%$ & $675.75 \%$ & $445.61 \%$ & 4.20 & 23.10 & 2.41 & $14.23 \%$ & $4.05 \%$ & $31.42 \%$ \\
\hline & 2016 & 2.55 & 2.04 & $67.93 \%$ & $77.19 \%$ & $338.31 \%$ & $291.55 \%$ & 9.48 & 12.37 & 2.48 & $3.24 \%$ & $2.18 \%$ & $9.57 \%$ \\
\hline \multirow[t]{3}{*}{ BYAN } & 2017 & 1.02 & 0.75 & $19.39 \%$ & $41.99 \%$ & $72.38 \%$ & $13.69 \%$ & 12.41 & 12.65 & 3.44 & $31.67 \%$ & $38.03 \%$ & $65.56 \%$ \\
\hline & 2018 & 1.24 & 0.93 & $57.70 \%$ & $41.08 \%$ & $69.73 \%$ & $11.14 \%$ & 16.79 & 13.82 & 3.41 & $31.27 \%$ & $45.56 \%$ & $77.32 \%$ \\
\hline & 2016 & 1.36 & 1.28 & $30.52 \%$ & $85.67 \%$ & $597.62 \%$ & $424.22 \%$ & 4.18 & 33.41 & 2.04 & $6.07 \%$ & $4.20 \%$ & $29.33 \%$ \\
\hline \multirow[t]{3}{*}{ DOID } & 2017 & 1.59 & 1.46 & $30.91 \%$ & $81.26 \%$ & $433.72 \%$ & $310.45 \%$ & 4.37 & 26.90 & 2.20 & $6.11 \%$ & $4.94 \%$ & $26.39 \%$ \\
\hline & 2018 & 1.58 & 1.46 & $23.89 \%$ & $47.09 \%$ & $89.01 \%$ & $44.51 \%$ & 4.02 & 26.70 & 2.02 & $8.48 \%$ & $6.39 \%$ & $12.07 \%$ \\
\hline & 2016 & 1.05 & 0.97 & $2.31 \%$ & $76.17 \%$ & $319.68 \%$ & $213.48 \%$ & 16.99 & 14.41 & 1.11 & $5.84 \%$ & $1.73 \%$ & $7.25 \%$ \\
\hline \multirow[t]{3}{*}{ FIRE } & 2017 & 2.67 & 2.52 & $24.20 \%$ & $50.92 \%$ & $103.76 \%$ & $68.75 \%$ & 4.94 & 14.60 & 0.84 & $0.60 \%$ & $0.23 \%$ & $0.47 \%$ \\
\hline & 2018 & 1.17 & 1.09 & $17.70 \%$ & $43.61 \%$ & $77.34 \%$ & $2.52 \%$ & 11.04 & 40.40 & 2.77 & $0.38 \%$ & $0.51 \%$ & $0.91 \%$ \\
\hline & 2016 & 1.66 & 1.44 & $72.87 \%$ & $43.20 \%$ & $76.04 \%$ & $28.26 \%$ & 6.15 & 12.75 & 1.68 & $14.40 \%$ & $10.90 \%$ & $19.18 \%$ \\
\hline \multirow[t]{3}{*}{ PTBA } & 2017 & 2.46 & 2.21 & $78.78 \%$ & $37.24 \%$ & $59.33 \%$ & $26.63 \%$ & 3.64 & 16.84 & 1.75 & $23.35 \%$ & $20.68 \%$ & $32.95 \%$ \\
\hline & 2018 & 2.38 & 2.06 & $127.67 \%$ & $32.69 \%$ & $48.58 \%$ & $18.24 \%$ & 7.61 & 13.65 & 1.80 & $24.19 \%$ & $21.19 \%$ & $31.48 \%$ \\
\hline & 2016 & 2.16 & 2.09 & $97.05 \%$ & $56.68 \%$ & $130.82 \%$ & $90.66 \%$ & 4.55 & 42.09 & 1.42 & $3.74 \%$ & $1.99 \%$ & $4.59 \%$ \\
\hline \multirow[t]{3}{*}{ PTRO } & 2017 & 1.65 & 1.58 & $59.03 \%$ & $59.13 \%$ & $144.68 \%$ & $90.13 \%$ & 3.87 & 35.68 & 1.61 & $3.20 \%$ & $1.90 \%$ & $4.66 \%$ \\
\hline & 2018 & 1.69 & 1.63 & $46.10 \%$ & $65.60 \%$ & $190.68 \%$ & $113.32 \%$ & 4.48 & 51.54 & 1.86 & $5.02 \%$ & $4.21 \%$ & $12.24 \%$ \\
\hline & 2016 & 0.17 & 0.15 & $0.80 \%$ & $82.96 \%$ & $486.69 \%$ & $121.12 \%$ & 1.16 & 3.43 & 0.33 & $-218.90 \%$ & $-7.72 \%$ & $-45.29 \%$ \\
\hline \multirow[t]{2}{*}{ ARII } & 2017 & 0.22 & 0.19 & $2.46 \%$ & $87.84 \%$ & $722.47 \%$ & $266.28 \%$ & 2.63 & 6.70 & 0.73 & $-58.18 \%$ & $-5.11 \%$ & $-42.04 \%$ \\
\hline & 2018 & 0.23 & 0.21 & $0.68 \%$ & $97.15 \%$ & $3412.59 \%$ & $1119.66 \%$ & 3.49 & 6.14 & 0.71 & $-74.05 \%$ & $-8.07 \%$ & $-283.54 \%$ \\
\hline
\end{tabular}

Pada tabel 2. terlihat hasil analisis rasio pada perusahaan batubara yang terdaftar di Bursa Efek Indonesia untuk tahun 2016 - 2018. Hasil tersebut kemudian menjadi data awal pengolahan menggunakan metode profile matching.

\section{Profile Matching}

Pengolahan metode profile matching digunakan untuk mengetahui peringkat aporan keuangan perusahaan batubara yang terdaftar di Bursa Efek Indonesia untuk tahun $2016 \quad-\quad 2018$.
Pengolahaanya terdiri dari beberapa tahapan, yaitu :

\section{Meghitung GAP}

Setelah diperoleh data awal, langkah selanjutnya adalah dengan menentukan nilai jarak (GAP) antara nilai rasio keuangan dengan nilai standar industri. Pemetaan ini dilakukan untuk mengukur kelebihan atau kekurangan rasio perusahaan berdasarkan standar industri. Kelebihan atau kekurangan ini menjadi dasar dalam menentukan rangking perusahaan.

Tabel 3. Perhitungan GAP

\begin{tabular}{|c|c|c|c|c|c|c|c|c|c|c|c|c|c|}
\hline \multirow{2}{*}{ Inisial } & \multirow{2}{*}{ Tahun } & \multicolumn{3}{|c|}{ Rasio Liquiditas } & \multicolumn{3}{|c|}{ Rasio Solvabilitas } & \multicolumn{3}{|c|}{ Rasio Aktifitas } & \multicolumn{3}{|c|}{ Rasio Profitabilitas } \\
\hline & & RL1 & RL2 & RL3 & RS1 & RS2 & RS3 & RA1 & RA2 & RA3 & RP1 & RP2 & RP3 \\
\hline \multirow{3}{*}{ ADRO } & 2016 & 0.47 & 0.86 & $117.08 \%$ & $6.95 \%$ & $-17.72 \%$ & $45.25 \%$ & $(6.61)$ & 14.38 & $(4.42)$ & $-19.64 \%$ & $-29.86 \%$ & $-39.76 \%$ \\
\hline & 2017 & 0.56 & 0.95 & $106.06 \%$ & $4.95 \%$ & $-23.46 \%$ & $37.64 \%$ & (6.21) & 18.12 & $(4.35)$ & $-19.43 \%$ & $-29.73 \%$ & $-39.54 \%$ \\
\hline & 2018 & $(0.04)$ & 0.32 & $63.65 \%$ & $4.06 \%$ & $-25.90 \%$ & $35.13 \%$ & $(3.50)$ & 12.32 & $(3.74)$ & $-19.35 \%$ & $-29.67 \%$ & $-39.45 \%$ \\
\hline \multirow{3}{*}{ ATPK } & 2016 & $(1.31)$ & $(1.03)$ & $-49.83 \%$ & $18.52 \%$ & $25.13 \%$ & $73.85 \%$ & $(14.90)$ & (19.80) & (5.94) & $-2733.38 \%$ & $-47.46 \%$ & $-77.55 \%$ \\
\hline & 2017 & $(1.80)$ & (1.47) & $-49.59 \%$ & $25.49 \%$ & $63.13 \%$ & $88.41 \%$ & 43.10 & $(19.55)$ & $(5.61)$ & $-1897.75 \%$ & $-61.22 \%$ & $-119.03 \%$ \\
\hline & 2018 & $(1.75)$ & (1.39) & $-49.78 \%$ & $34.46 \%$ & $137.40 \%$ & $137.12 \%$ & (12.78) & (18.65) & (5.23) & $-352.14 \%$ & $-45.75 \%$ & $-91.55 \%$ \\
\hline \multirow{3}{*}{ MBAP } & 2016 & 1.41 & 1.47 & $133.26 \%$ & $-13.74 \%$ & $-62.99 \%$ & $-7.22 \%$ & $(7.45)$ & $(0.89)$ & (3.53) & $-0.69 \%$ & $1.06 \%$ & $-0.55 \%$ \\
\hline & 2017 & 1.16 & 1.05 & $154.08 \%$ & $-11.07 \%$ & $-58.54 \%$ & $-6.61 \%$ & 0.40 & (7.78) & (3.62) & $10.39 \%$ & $18.88 \%$ & $24.25 \%$ \\
\hline & 2018 & 0.64 & 0.58 & $82.71 \%$ & $-6.57 \%$ & $-50.28 \%$ & $-3.20 \%$ & (6.16) & (8.69) & (3.61) & $6.10 \%$ & $8.83 \%$ & $14.25 \%$ \\
\hline \multirow{3}{*}{ SMMT } & 2016 & (1.73) & (1.27) & $-30.78 \%$ & $5.13 \%$ & $-22.96 \%$ & $35.64 \%$ & 40.11 & (1.21) & (3. & $12.61 \%$ & $-27.13 \%$ & $-35.20 \%$ \\
\hline & 2017 & $(1.52)$ & (1.04) & $-35.56 \%$ & $1.82 \%$ & $-31.73 \%$ & $25.31 \%$ & (7.61) & 1.58 & $(5.00)$ & $49.53 \%$ & $-25.18 \%$ & $-32.38 \%$ \\
\hline & 2018 & (1.85) & (1.37) & $-24.05 \%$ & $10.57 \%$ & $-6.28 \%$ & $30.73 \%$ & 28.86 & 51.29 & 1.38 & $24.42 \%$ & $-18.74 \%$ & $-19.32 \%$ \\
\hline
\end{tabular}




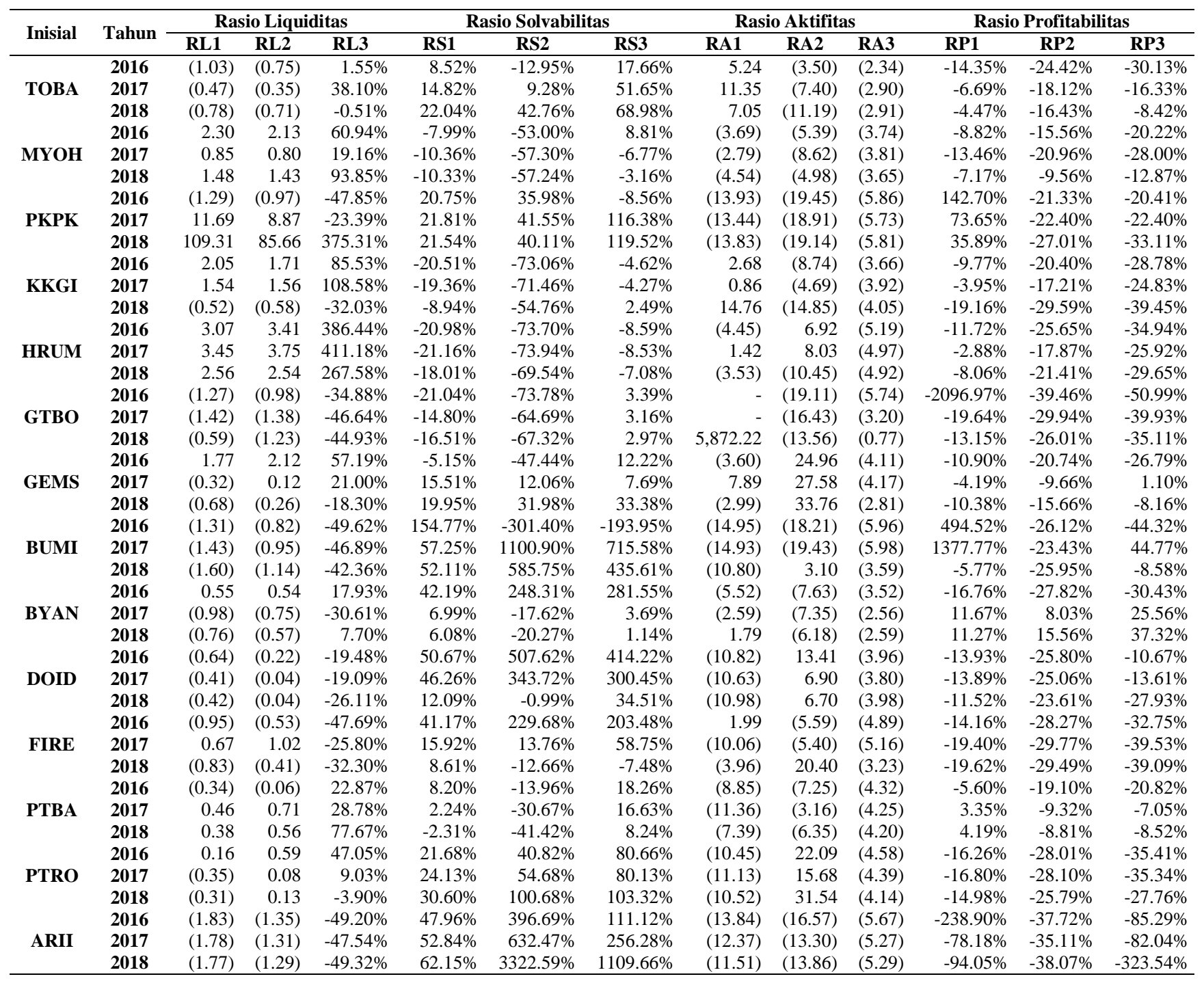

\section{Pembobotan}

Pemberian nilai bobot dilakukan untuk mengatahui nilai bobot dari GAP rasio yang telah didapatkan. Setelah nilai bobot dihitung untuk seluruh perusahaan maka didapatkan hasil perhitungan ini seperti tabel 4 .

Tabel 4. Perhitungan Pembobotan

\begin{tabular}{|c|c|c|c|c|c|c|c|c|c|c|c|c|c|}
\hline \multirow{2}{*}{ Inisial } & \multirow{2}{*}{ Tahun } & \multicolumn{3}{|c|}{ RasioLiquiditas } & \multicolumn{3}{|c|}{ RasioSolvabilitas } & \multicolumn{3}{|c|}{ RasioAktifitas } & \multicolumn{3}{|c|}{ RasioProfitabilitas } \\
\hline & & RL1 & RL2 & RL3 & RS1 & RS2 & RS3 & RA1 & RA2 & RA3 & RP1 & RP2 & RP3 \\
\hline \multirow{3}{*}{ ADRO } & 2016 & 5.24 & 5.43 & 5.59 & 5.03 & 4.91 & 5.23 & 1.70 & 12.19 & 2.79 & 4.90 & 4.85 & 4.80 \\
\hline & 2017 & 5.28 & 5.47 & 5.53 & 5.02 & 4.88 & 5.19 & 1.89 & 14.06 & 2.82 & 4.90 & 4.85 & 4.80 \\
\hline & 2018 & 4.98 & 5.16 & 5.32 & 5.02 & 4.87 & 5.18 & 3.25 & 11.16 & 3.13 & 4.90 & 4.85 & 4.80 \\
\hline \multirow{4}{*}{ ATPK } & 2016 & 4.34 & 4.48 & 4.75 & 5.09 & 5.13 & 5.37 & $(2.45)$ & $(4.90)$ & 2.03 & $(8.67)$ & 4.76 & 4.61 \\
\hline & 2017 & 4.10 & 4.26 & 4.75 & 5.13 & 5.32 & 5.44 & 26.55 & $(4.77)$ & 2.20 & $(4.49)$ & 4.69 & 4.40 \\
\hline & 8 & 4.13 & 4.30 & 4.75 & 5.17 & 5.69 & 5.69 & (1.39) & (4.32) & 2.38 & 3.24 & 4.77 & 4.54 \\
\hline & 2016 & 5.70 & 5.73 & 5.67 & 4.93 & 4.69 & 4.96 & 1.28 & 4.55 & 3.24 & 5.00 & 5.01 & 5.00 \\
\hline \multirow[t]{3}{*}{ MBAP } & 2017 & 5.58 & 5.52 & 5.77 & 4.94 & 4.71 & 4.97 & 5.20 & 1.11 & 3.19 & 5.05 & 5.09 & 5.12 \\
\hline & 2018 & 5.32 & 5.29 & 5.41 & 4.97 & 4.75 & 4.98 & 1.92 & 0.65 & 3.20 & 5.03 & 5.04 & 5.07 \\
\hline & & 4.13 & 4.36 & 4.85 & 5.03 & 4.89 & 5. & 25.05 & 4.40 & 3.29 & 5.06 & 4.86 & 4.82 \\
\hline \multirow[t]{3}{*}{ SMMT } & 2017 & 4.24 & 4.48 & 4.82 & 5.01 & 4.84 & 5.13 & 1.19 & 5.79 & 2.50 & 5.25 & 4.87 & 4.84 \\
\hline & 2018 & 4.07 & 4.32 & 4.88 & 5.05 & 4.97 & 5.15 & 19.43 & 30.65 & 5.69 & 5.12 & 4.91 & 4.90 \\
\hline & 2016 & 4.48 & 4.63 & 5.01 & 5.04 & 4.94 & 5.09 & 7.62 & 3.25 & 3.83 & 4.93 & 4.88 & 4.85 \\
\hline \multirow[t]{2}{*}{ TOBA } & 2017 & 4.76 & 4.83 & 5.19 & 5.07 & 5.05 & 5.26 & 10.67 & 1.30 & 3.55 & 4.97 & 4.91 & 4.92 \\
\hline & 2018 & 4.61 & 4.65 & 5.00 & 5.11 & 5.21 & 5.34 & 8.52 & $(0.60)$ & 3.54 & 4.98 & 4.92 & 4.96 \\
\hline МYОН & 2016 & 6.15 & 6.07 & 5.30 & 4.96 & 4.74 & 5.04 & 3.16 & 2.31 & 3.13 & 4.96 & 4.92 & 4.90 \\
\hline
\end{tabular}




\begin{tabular}{|c|c|c|c|c|c|c|c|c|c|c|c|c|c|}
\hline \multirow{2}{*}{ Inisial } & \multirow{2}{*}{ Tahun } & \multicolumn{3}{|c|}{ RasioLiquiditas } & \multicolumn{3}{|c|}{ RasioSolvabilitas } & \multicolumn{3}{|c|}{ RasioAktifitas } & \multicolumn{3}{|c|}{ RasioProfitabilitas } \\
\hline & & RL1 & RL2 & RL3 & RS1 & RS2 & RS3 & RA1 & RA2 & RA3 & RP1 & RP2 & RP3 \\
\hline & 2017 & 5.42 & 5.40 & 5.10 & 4.95 & 4.71 & 4.97 & 3.61 & 0.69 & 3.09 & 4.93 & 4.90 & 4.86 \\
\hline & 2018 & 5.74 & 5.72 & 5.47 & 4.95 & 4.71 & 4.98 & 2.73 & 2.51 & 3.17 & 4.96 & 4.95 & 4.94 \\
\hline & 2016 & 4.35 & 4.52 & 4.76 & 5.10 & 5.18 & 4.96 & (1.96) & $(4.72)$ & 2.07 & 5.71 & 4.89 & 4.90 \\
\hline \multirow[t]{3}{*}{ PKPK } & 2017 & 10.85 & 9.43 & 4.88 & 5.11 & 5.21 & 5.58 & (1.72) & $(4.45)$ & 2.13 & 5.37 & 4.89 & 4.89 \\
\hline & 2018 & 59.66 & 47.83 & 6.88 & 5.11 & 5.20 & 5.60 & (1.92) & $(4.57)$ & 2.09 & 5.18 & 4.86 & 4.83 \\
\hline & 2016 & 6.03 & 5.85 & 5.43 & 4.90 & 4.63 & 4.98 & 6.34 & 0.63 & 3.17 & 4.95 & 4.90 & 4.86 \\
\hline \multirow{3}{*}{ KKGI } & 2017 & 5.77 & 5.78 & 5.54 & 4.90 & 4.64 & 4.98 & 5.43 & 2.65 & 3.04 & 4.98 & 4.91 & 4.88 \\
\hline & 2018 & 4.74 & 4.71 & 4.84 & 4.96 & 4.73 & 5.01 & 12.38 & $(2.43)$ & 2.98 & 4.90 & 4.85 & 4.80 \\
\hline & 2016 & 6.53 & 6.71 & 6.93 & 4.90 & 4.63 & 4.96 & 2.78 & 8.46 & 2.40 & 4.94 & 4.87 & 4.83 \\
\hline \multirow{3}{*}{ HRUM } & 2017 & 6.73 & 6.87 & 7.06 & 4.89 & 4.63 & 4.96 & 5.71 & 9.01 & 2.52 & 4.99 & 4.91 & 4.87 \\
\hline & 2018 & 6.28 & 6.27 & 6.34 & 4.91 & 4.65 & 4.96 & 3.23 & $(0.23)$ & 2.54 & 4.96 & 4.89 & 4.85 \\
\hline & 2016 & 4.36 & 4.51 & 4.83 & 4.89 & 4.63 & 5.02 & 5.00 & $(4.55)$ & 2.13 & $(5.48)$ & 4.80 & 4.75 \\
\hline \multirow[t]{3}{*}{ GTBO } & 2017 & 4.29 & 4.31 & 4.77 & 4.93 & 4.68 & 5.02 & 5.00 & (3.21) & 3.40 & 4.90 & 4.85 & 4.80 \\
\hline & 2018 & 4.70 & 4.38 & 4.78 & 4.92 & 4.66 & 5.01 & 941.11 & (1.78) & 4.61 & 4.93 & 4.87 & 4.82 \\
\hline & 2016 & 5.89 & 6.06 & 5.29 & 4.97 & 4.76 & 5.06 & 3.20 & 17.48 & 2.94 & 4.95 & 4.90 & 4.87 \\
\hline \multirow[t]{3}{*}{ GEMS } & 2017 & 4.84 & 5.06 & 5.10 & 5.08 & 5.06 & 5.04 & 8.95 & 18.79 & 2.92 & 4.98 & 4.95 & 5.01 \\
\hline & 2018 & 4.66 & 4.87 & 4.91 & 5.10 & 5.16 & 5.17 & 3.51 & 21.88 & 3.60 & 4.95 & 4.92 & 4.96 \\
\hline & 2016 & 4.35 & 4.59 & 4.75 & 5.77 & 3.49 & 4.03 & $(2.48)$ & (4.11) & 2.02 & 7.47 & 4.87 & 4.78 \\
\hline \multirow[t]{3}{*}{ BUMI } & 2017 & 4.28 & 4.52 & 4.77 & 5.29 & 10.50 & 8.58 & (2.47) & (4.72) & 2.01 & 11.89 & 4.88 & 5.22 \\
\hline & 2018 & 4.20 & 4.43 & 4.79 & 5.26 & 7.93 & 7.18 & $(0.40)$ & 6.55 & 3.21 & 4.97 & 4.87 & 4.96 \\
\hline & 2016 & 5.27 & 5.27 & 5.09 & 5.21 & 6.24 & 6.41 & 2.24 & 1.19 & 3.24 & 4.92 & 4.86 & 4.85 \\
\hline \multirow[t]{3}{*}{ BYAN } & 2017 & 4.51 & 4.62 & 4.85 & 5.03 & 4.91 & 5.02 & 3.70 & 1.32 & 3.72 & 5.06 & 5.04 & 5.13 \\
\hline & 2018 & 4.62 & 4.72 & 5.04 & 5.03 & 4.90 & 5.01 & 5.90 & 1.91 & 3.71 & 5.06 & 5.08 & 5.19 \\
\hline & 2016 & 4.68 & 4.89 & 4.90 & 5.25 & 7.54 & 7.07 & $(0.41)$ & 11.71 & 3.02 & 4.93 & 4.87 & 4.95 \\
\hline \multirow[t]{3}{*}{ DOID } & 2017 & 4.79 & 4.98 & 4.90 & 5.23 & 6.72 & 6.50 & $(0.31)$ & 8.45 & 3.10 & 4.93 & 4.87 & 4.93 \\
\hline & 2018 & 4.79 & 4.98 & 4.87 & 5.06 & 5.00 & 5.17 & $(0.49)$ & 8.35 & 3.01 & 4.94 & 4.88 & 4.86 \\
\hline & 2016 & 4.53 & 4.74 & 4.76 & 5.21 & 6.15 & 6.02 & 6.00 & 2.21 & 2.56 & 4.93 & 4.86 & 4.84 \\
\hline \multirow{3}{*}{ FIRE } & 2017 & 5.34 & 5.51 & 4.87 & 5.08 & 5.07 & 5.29 & $(0.03)$ & 2.30 & 2.42 & 4.90 & 4.85 & 4.80 \\
\hline & 2018 & 4.59 & 4.80 & 4.84 & 5.04 & 4.94 & 4.96 & 3.02 & 15.20 & 3.38 & 4.90 & 4.85 & 4.80 \\
\hline & 2016 & 4.83 & 4.97 & 5.11 & 5.04 & 4.93 & 5.09 & 0.58 & 1.38 & 2.84 & 4.97 & 4.90 & 4.90 \\
\hline \multirow{3}{*}{ PTBA } & 2017 & 5.23 & 5.35 & 5.14 & 5.01 & 4.85 & 5.08 & $(0.68)$ & 3.42 & 2.88 & 5.02 & 4.95 & 4.96 \\
\hline & 2018 & 5.19 & 5.28 & 5.39 & 4.99 & 4.79 & 5.04 & 1.30 & 1.82 & 2.90 & 5.02 & 4.96 & 4.96 \\
\hline & 2016 & 5.08 & 5.29 & 5.24 & 5.11 & 5.20 & 5.40 & $(0.22)$ & 16.05 & 2.71 & 4.92 & 4.86 & 4.82 \\
\hline \multirow[t]{3}{*}{ PTRO } & 2017 & 4.83 & 5.04 & 5.05 & 5.12 & 5.27 & 5.40 & $(0.57)$ & 12.84 & 2.81 & 4.92 & 4.86 & 4.82 \\
\hline & 2018 & 4.85 & 5.07 & 4.98 & 5.15 & 5.50 & 5.52 & $(0.26)$ & 20.77 & 2.93 & 4.93 & 4.87 & 4.86 \\
\hline & 2016 & 4.08 & 4.33 & 4.75 & 5.24 & 6.98 & 5.56 & (1.92) & (3.28) & 2.17 & 3.81 & 4.81 & 4.57 \\
\hline \multirow[t]{2}{*}{ ARII } & 2017 & 4.11 & 4.35 & 4.76 & 5.26 & 8.16 & 6.28 & (1.18) & (1.65) & 2.36 & 4.61 & 4.82 & 4.59 \\
\hline & 2018 & 4.12 & 4.35 & 4.75 & 5.31 & 21.61 & 10.55 & $(0.75)$ & (1.93) & 2.36 & 4.53 & 4.81 & 3.38 \\
\hline
\end{tabular}

\section{Core Factor \& Secondary Factor}

Perhitungan Core Factor dan

Secondari Factor digunakan untun menentukan nilai masing masing sub rasio dari rasio keuangan, yang mana dikelompokkan menjadi faktor utama dan faktor pendukung. Faktor utama dari sub rasio digunakan dua sub rasio pertama dari masing masing rasio keuangan. Sedangkan faktor pendukung menggunakan rasio ketiga dari masing masing rasio keuangan.

Tabel 5. Perhitungan CF \& SF

\begin{tabular}{|c|c|c|c|c|c|c|c|c|c|}
\hline \multirow{2}{*}{ Inisial } & \multirow{2}{*}{ Tahun } & \multicolumn{2}{|c|}{ Rasio Liuiditas } & \multicolumn{2}{|c|}{ Rasio Solvabilitas } & \multicolumn{2}{|c|}{ Rasio Aktivitas } & \multicolumn{2}{|c|}{ Rasio Profitabilitas } \\
\hline & & CF & SF & CF & SF & CF & SF & CF & SF \\
\hline \multirow{3}{*}{ ADRO } & 2016 & 5.33 & 5.59 & 4.97 & 5.23 & 6.94 & 2.79 & 4.88 & 4.80 \\
\hline & 2017 & 5.38 & 5.53 & 4.95 & 5.19 & 7.98 & 2.82 & 4.88 & 4.80 \\
\hline & 2018 & 5.07 & 5.32 & 4.95 & 5.18 & 7.20 & 3.13 & 4.88 & 4.80 \\
\hline \multirow{3}{*}{ ATPK } & 2016 & 4.41 & 4.75 & 5.11 & 5.37 & $(3.68)$ & 2.03 & $(1.95)$ & 4.61 \\
\hline & 2017 & 4.18 & 4.75 & 5.22 & 5.44 & 10.89 & 2.20 & 0.10 & 4.40 \\
\hline & 2018 & 4.22 & 4.75 & 5.43 & 5.69 & $(2.86)$ & 2.38 & 4.01 & 4.54 \\
\hline \multirow{3}{*}{ MBAP } & 2016 & 5.72 & 5.67 & 4.81 & 4.96 & 2.91 & 3.24 & 5.00 & 5.00 \\
\hline & 2017 & 5.55 & 5.77 & 4.83 & 4.97 & 3.15 & 3.19 & 5.07 & 5.12 \\
\hline & 2018 & 5.30 & 5.41 & 4.86 & 4.98 & 1.29 & 3.20 & 5.04 & 5.07 \\
\hline \multirow{3}{*}{ SMMT } & 2016 & 4.25 & 4.85 & 4.96 & 5.18 & 14.73 & 3.29 & 4.96 & 4.82 \\
\hline & 2017 & 4.36 & 4.82 & 4.93 & 5.13 & 3.49 & 2.50 & 5.06 & 4.84 \\
\hline & 2018 & 4.19 & 4.88 & 5.01 & 5.15 & 25.04 & 5.69 & 5.01 & 4.90 \\
\hline
\end{tabular}




\begin{tabular}{|c|c|c|c|c|c|c|c|c|c|}
\hline \multirow{2}{*}{ Inisial } & \multirow{2}{*}{ Tahun } & \multicolumn{2}{|c|}{ Rasio Liuiditas } & \multicolumn{2}{|c|}{ Rasio Solvabilitas } & \multicolumn{2}{|c|}{ Rasio Aktivitas } & \multicolumn{2}{|c|}{ Rasio Profitabilitas } \\
\hline & & $\mathbf{C F}$ & SF & $\mathbf{C F}$ & SF & $\mathbf{C F}$ & SF & $\mathbf{C F}$ & SF \\
\hline \multirow{3}{*}{ TOBA } & 2016 & 4.56 & 5.01 & 4.99 & 5.09 & 5.43 & 3.83 & 4.90 & 4.85 \\
\hline & 2017 & 4.79 & 5.19 & 5.06 & 5.26 & 5.99 & 3.55 & 4.94 & 4.92 \\
\hline & 2018 & 4.63 & 5.00 & 5.16 & 5.34 & 3.96 & 3.54 & 4.95 & 4.96 \\
\hline & 2016 & 6.11 & 5.30 & 4.85 & 5.04 & 2.73 & 3.13 & 4.94 & 4.90 \\
\hline \multirow[t]{3}{*}{ МYOH } & 2017 & 5.41 & 5.10 & 4.83 & 4.97 & 2.15 & 3.09 & 4.91 & 4.86 \\
\hline & 2018 & 5.73 & 5.47 & 4.83 & 4.98 & 2.62 & 3.17 & 4.96 & 4.94 \\
\hline & 2016 & 4.43 & 4.76 & 5.14 & 4.96 & $(3.34)$ & 2.07 & 5.30 & 4.90 \\
\hline \multirow[t]{3}{*}{ PKPK } & 2017 & 10.14 & 4.88 & 5.16 & 5.58 & (3.09) & 2.13 & 5.13 & 4.89 \\
\hline & 2018 & 53.74 & 6.88 & 5.15 & 5.60 & (3.24) & 2.09 & 5.02 & 4.83 \\
\hline & 2016 & 5.94 & 5.43 & 4.77 & 4.98 & 3.48 & 3.17 & 4.92 & 4.86 \\
\hline \multirow[t]{3}{*}{ KKGI } & 2017 & 5.77 & 5.54 & 4.77 & 4.98 & 4.04 & 3.04 & 4.95 & 4.88 \\
\hline & 2018 & 4.72 & 4.84 & 4.84 & 5.01 & 4.98 & 2.98 & 4.88 & 4.80 \\
\hline & 2016 & 6.62 & 6.93 & 4.76 & 4.96 & 5.62 & 2.40 & 4.91 & 4.83 \\
\hline \multirow[t]{3}{*}{ HRUM } & 2017 & 6.80 & 7.06 & 4.76 & 4.96 & 7.36 & 2.52 & 4.95 & 4.87 \\
\hline & 2018 & 6.28 & 6.34 & 4.78 & 4.96 & 1.50 & 2.54 & 4.93 & 4.85 \\
\hline & 2016 & 4.44 & 4.83 & 4.76 & 5.02 & 0.22 & 2.13 & $(0.34)$ & 4.75 \\
\hline \multirow[t]{2}{*}{ GTBO } & 2017 & 4.30 & 4.77 & 4.80 & 5.02 & 0.89 & 3.40 & 4.88 & 4.80 \\
\hline & 2018 & 4.54 & 4.78 & 4.79 & 5.01 & $1,469.67$ & 4.61 & 4.90 & 4.82 \\
\hline \multirow{4}{*}{ GEMS } & 2016 & 5.97 & 5.29 & 4.87 & 5.06 & 10.34 & 2.94 & 4.92 & 4.87 \\
\hline & 2017 & 4.95 & 5.10 & 5.07 & 5.04 & 13.87 & 2.92 & 4.97 & 5.01 \\
\hline & 2018 & 4.77 & 4.91 & 5.13 & 5.17 & 12.69 & 3.60 & 4.93 & 4.96 \\
\hline & 2016 & 4.47 & 4.75 & 4.63 & 4.03 & (3.29) & 2.02 & 6.17 & 4.78 \\
\hline \multirow[t]{3}{*}{ BUMI } & 2017 & 4.40 & 4.77 & 7.90 & 8.58 & (3.59) & 2.01 & 8.39 & 5.22 \\
\hline & 2018 & 4.31 & 4.79 & 6.59 & 7.18 & 3.07 & 3.21 & 4.92 & 4.96 \\
\hline & 2016 & 5.27 & 5.09 & 5.73 & 6.41 & 1.71 & 3.24 & 4.89 & 4.85 \\
\hline \multirow{3}{*}{ BYAN } & 2017 & 4.57 & 4.85 & 4.97 & 5.02 & 2.51 & 3.72 & 5.05 & 5.13 \\
\hline & 2018 & 4.67 & 5.04 & 4.96 & 5.01 & 3.90 & 3.71 & 5.07 & 5.19 \\
\hline & 2016 & 4.79 & 4.90 & 6.40 & 7.07 & 5.65 & 3.02 & 4.90 & 4.95 \\
\hline \multirow[t]{3}{*}{ DOID } & 2017 & 4.89 & 4.90 & 5.97 & 6.50 & 4.07 & 3.10 & 4.90 & 4.93 \\
\hline & 2018 & 4.89 & 4.87 & 5.03 & 5.17 & 3.93 & 3.01 & 4.91 & 4.86 \\
\hline & 2016 & 4.63 & 4.76 & 5.68 & 6.02 & 4.10 & 2.56 & 4.89 & 4.84 \\
\hline \multirow[t]{3}{*}{ FIRE } & 2017 & 5.42 & 4.87 & 5.07 & 5.29 & 1.13 & 2.42 & 4.88 & 4.80 \\
\hline & 2018 & 4.69 & 4.84 & 4.99 & 4.96 & 9.11 & 3.38 & 4.88 & 4.80 \\
\hline & 2016 & 4.90 & 5.11 & 4.99 & 5.09 & 0.98 & 2.84 & 4.94 & 4.90 \\
\hline \multirow[t]{3}{*}{ PTBA } & 2017 & 5.29 & 5.14 & 4.93 & 5.08 & 1.37 & 2.88 & 4.99 & 4.96 \\
\hline & 2018 & 5.24 & 5.39 & 4.89 & 5.04 & 1.56 & 2.90 & 4.99 & 4.96 \\
\hline & 2016 & 5.19 & 5.24 & 5.16 & 5.40 & 7.91 & 2.71 & 4.89 & 4.82 \\
\hline \multirow[t]{3}{*}{ PTRO } & 2017 & 4.93 & 5.05 & 5.20 & 5.40 & 6.14 & 2.81 & 4.89 & 4.82 \\
\hline & 2018 & 4.96 & 4.98 & 5.33 & 5.52 & 10.25 & 2.93 & 4.90 & 4.86 \\
\hline & 2016 & 4.21 & 4.75 & 6.11 & 5.56 & $(2.60)$ & 2.17 & 4.31 & 4.57 \\
\hline \multirow[t]{2}{*}{ ARII } & 2017 & 4.23 & 4.76 & 6.71 & 6.28 & $(1.42)$ & 2.36 & 4.72 & 4.59 \\
\hline & 2018 & 4.24 & 4.75 & 13.46 & 10.55 & (1.34) & 2.36 & 4.67 & 3.38 \\
\hline
\end{tabular}

4. Nilai Total

Setelah didapatkan nilai Core Factor dan Secondari Factor untuk setiap perusahaan berdasarkan raio keuangan, langkah selanjutnya adalah menjumlahkan masing masing nilai Core Factor dan Secondari Factor rasio keuangan.

$$
N=(60 \% \times N C F)+(40 \% \times N S F)
$$

Tabel 6. Nilai Total

\begin{tabular}{cccccc}
\hline Inisial & Tahun & Rasio Liquiditas & Rasio Solvabilitas & Rasio Aktivitas & Rasio Profitabilitas \\
\hline \multirow{3}{*}{ ADRO } & $\mathbf{2 0 1 6}$ & 9.18 & 5.07 & 5.28 & 4.85 \\
& $\mathbf{2 0 1 7}$ & 9.16 & 5.05 & 5.92 & 4.85 \\
& $\mathbf{2 0 1 8}$ & 8.76 & 5.04 & 5.58 & 4.85 \\
\hline
\end{tabular}




\begin{tabular}{|c|c|c|c|c|c|}
\hline Inisial & Tahun & Rasio Liquiditas & Rasio Solvabilitas & Rasio Aktivitas & Rasio Profitabilitas \\
\hline & 2016 & 7.80 & 5.21 & $(1.39)$ & 0.67 \\
\hline \multirow{3}{*}{ ATPK } & 2017 & 7.66 & 5.31 & 7.41 & 1.82 \\
\hline & 2018 & 7.68 & 5.53 & $(0.76)$ & 4.22 \\
\hline & 2016 & 9.50 & 4.87 & 3.04 & 5.00 \\
\hline \multirow[t]{3}{*}{ MBAP } & 2017 & 9.50 & 4.88 & 3.17 & 5.09 \\
\hline & 2018 & 9.00 & 4.91 & 2.05 & 5.05 \\
\hline & 2016 & 7.80 & 5.04 & 10.15 & 4.91 \\
\hline \multirow[t]{3}{*}{ SMMT } & 2017 & 7.84 & 5.01 & 3.09 & 4.97 \\
\hline & 2018 & 7.80 & 5.07 & 17.30 & 4.97 \\
\hline & 2016 & 8.14 & 5.03 & 4.79 & 4.88 \\
\hline \multirow{3}{*}{ TOBA } & 2017 & 8.47 & 5.14 & 5.01 & 4.93 \\
\hline & 2018 & 8.18 & 5.24 & 3.80 & 4.95 \\
\hline & 2016 & 9.37 & 4.93 & 2.89 & 4.92 \\
\hline \multirow[t]{3}{*}{ МYОН } & 2017 & 8.74 & 4.88 & 2.53 & 4.89 \\
\hline & 2018 & 9.31 & 4.89 & 2.84 & 4.95 \\
\hline & 2016 & 7.82 & 5.07 & (1.18) & 5.14 \\
\hline \multirow[t]{3}{*}{ PKPK } & 2017 & 11.37 & 5.33 & (1.00) & 5.03 \\
\hline & 2018 & 39.52 & 5.33 & (1.11) & 4.95 \\
\hline & 2016 & 9.39 & 4.85 & 3.36 & 4.90 \\
\hline \multirow{3}{*}{ KKGI } & 2017 & 9.41 & 4.86 & 3.64 & 4.92 \\
\hline & 2018 & 8.07 & 4.91 & 4.18 & 4.85 \\
\hline & 2016 & 11.30 & 4.84 & 4.33 & 4.87 \\
\hline \multirow[t]{3}{*}{ HRUM } & 2017 & 11.54 & 4.84 & 5.42 & 4.92 \\
\hline & 2018 & 10.50 & 4.85 & 1.92 & 4.90 \\
\hline & 2016 & 7.89 & 4.86 & 0.99 & 1.69 \\
\hline \multirow[t]{3}{*}{ GTBO } & 2017 & 7.75 & 4.89 & 1.90 & 4.85 \\
\hline & 2018 & 7.90 & 4.88 & 883.65 & 4.87 \\
\hline & 2016 & 9.27 & 4.95 & 7.38 & 4.90 \\
\hline \multirow[t]{3}{*}{ GEMS } & 2017 & 8.47 & 5.06 & 9.49 & 4.98 \\
\hline & 2018 & 8.17 & 5.14 & 9.05 & 4.94 \\
\hline & 2016 & 7.83 & 4.39 & (1.17) & 5.61 \\
\hline \multirow[t]{3}{*}{ BUMI } & 2017 & 7.81 & 8.17 & (1.35) & 7.12 \\
\hline & 2018 & 7.78 & 6.83 & 3.13 & 4.94 \\
\hline & 2016 & 8.65 & 6.00 & 2.32 & 4.87 \\
\hline \multirow[t]{3}{*}{ BYAN } & 2017 & 7.99 & 4.99 & 3.00 & 5.08 \\
\hline & 2018 & 8.24 & 4.98 & 3.82 & 5.11 \\
\hline & 2016 & 8.17 & 6.67 & 4.60 & 4.92 \\
\hline \multirow[t]{3}{*}{ DOID } & 2017 & 8.24 & 6.19 & 3.68 & 4.91 \\
\hline & 2018 & 8.20 & 5.09 & 3.56 & 4.89 \\
\hline & 2016 & 7.94 & 5.81 & 3.48 & 4.87 \\
\hline \multirow[t]{3}{*}{ FIRE } & 2017 & 8.53 & 5.16 & 1.65 & 4.85 \\
\hline & 2018 & 8.05 & 4.98 & 6.82 & 4.85 \\
\hline & 2016 & 8.45 & 5.03 & 1.72 & 4.92 \\
\hline \multirow[t]{3}{*}{ PTBA } & 2017 & 8.72 & 4.99 & 1.97 & 4.98 \\
\hline & 2018 & 8.93 & 4.95 & 2.10 & 4.98 \\
\hline & 2016 & 8.75 & 5.26 & 5.83 & 4.86 \\
\hline \multirow[t]{3}{*}{ PTRO } & 2017 & 8.41 & 5.28 & 4.81 & 4.86 \\
\hline & 2018 & 8.35 & 5.40 & 7.33 & 4.88 \\
\hline & 2016 & 7.68 & 5.89 & (0.69) & 4.41 \\
\hline \multirow[t]{2}{*}{ ARII } & 2017 & 7.70 & 6.54 & 0.09 & 4.67 \\
\hline & 2018 & 7.69 & 12.30 & 0.14 & 4.15 \\
\hline
\end{tabular}

\section{Nilai Rangking}

Setelah didapatkan nilai total untuk setiap rasio keuangan, langkah selanjutnya adalah menjumlahkan seluruh rasio keuangan berdasarkan presentase nilai rasio tersebut. 


\begin{tabular}{|c|c|c|c|}
\hline Nama Perusahaan & Inisial & Tahun & Nilai Rangking \\
\hline \multirow{3}{*}{ ADARO ENERGY TBK } & \multirow{3}{*}{ ADRO } & 2016 & 4.03 \\
\hline & & 2017 & 4.16 \\
\hline & & 2018 & 3.99 \\
\hline \multirow{3}{*}{$\begin{array}{c}\text { BARA JAYA } \\
\text { INTERNASIONALTBK }\end{array}$} & \multirow{3}{*}{ ATPK } & 2016 & 0.86 \\
\hline & & 2017 & 2.97 \\
\hline & & 2018 & 2.14 \\
\hline \multirow{3}{*}{$\begin{array}{c}\text { MITRABARA } \\
\text { ADIPERDANA TBK }\end{array}$} & \multirow{3}{*}{ MBAP } & 2016 & 3.76 \\
\hline & & 2017 & 3.82 \\
\hline & & 2018 & 3.45 \\
\hline \multirow{3}{*}{$\begin{array}{l}\text { GOLDEN EAGLE } \\
\text { ENERGY TBK }\end{array}$} & \multirow{3}{*}{ SMMT } & 2016 & 4.69 \\
\hline & & 2017 & 3.32 \\
\hline & & 2018 & 6.13 \\
\hline \multirow{3}{*}{$\begin{array}{c}\text { TOBA BARA } \\
\text { SEJAHTERA TBK }\end{array}$} & \multirow{3}{*}{ TOBA } & 2016 & 3.70 \\
\hline & & 2017 & 3.82 \\
\hline & & 2018 & 3.49 \\
\hline \multirow{3}{*}{$\begin{array}{c}\text { SAMINDO } \\
\text { RESOURCE TBK }\end{array}$} & \multirow{3}{*}{ МYOH } & 2016 & 3.66 \\
\hline & & 2017 & 3.43 \\
\hline & & 2018 & 3.65 \\
\hline \multirow{3}{*}{$\begin{array}{l}\text { PERDANA KARYA } \\
\text { PERKASA }\end{array}$} & \multirow{3}{*}{ PKPK } & 2016 & 2.51 \\
\hline & & 2017 & 3.34 \\
\hline & & 2018 & 10.32 \\
\hline \multirow{4}{*}{$\begin{array}{l}\text { RESOURCE ALAM } \\
\text { INDONESIA }\end{array}$} & \multirow{4}{*}{ KKGI } & 2016 & 3.76 \\
\hline & & 2017 & 3.83 \\
\hline & & 2018 & 3.57 \\
\hline & & 2016 & 4.43 \\
\hline \multirow{2}{*}{ HARUM ENERGY } & \multirow[t]{2}{*}{ HRUM } & 2017 & 4.72 \\
\hline & & 2018 & 3.75 \\
\hline \multirow{3}{*}{$\begin{array}{l}\text { GARDA TUJUH } \\
\text { BUANA }\end{array}$} & \multirow{3}{*}{ GTBO } & 2016 & 1.79 \\
\hline & & 2017 & 3.03 \\
\hline & & 2018 & 179.43 \\
\hline & & 2016 & 4.52 \\
\hline GULDEN ENEKGY & GEMS & 2017 & 4.75 \\
\hline & & 2018 & 4.55 \\
\hline & & 2016 & 2.81 \\
\hline BUMI RESOURCE & BUMI & 2017 & 2.54 \\
\hline & & 2018 & 2.93 \\
\hline & & 2016 & 3.13 \\
\hline BAYAN RESOURCE & BYAN & 2017 & 3.38 \\
\hline & & 2018 & 3.62 \\
\hline & & 2016 & 3.35 \\
\hline DELTA DUNIA & DOID & 2017 & 3.28 \\
\hline & & 2018 & 3.46 \\
\hline & & 2016 & 3.22 \\
\hline ALFA ENERGI & FIRE & 2017 & 3.13 \\
\hline INVESTAM & & 2018 & 4.08 \\
\hline TAMBANG & & 2016 & 3.17 \\
\hline BATUBARA BUKIT & PTBA & 2017 & 3.32 \\
\hline ASAM (PERSERO) & & 2018 & 3.40 \\
\hline & & 2016 & 4.00 \\
\hline PETROSEA & PTRO & 2017 & 3.71 \\
\hline & & 2018 & 4.18 \\
\hline & & 2016 & 2.15 \\
\hline ATLAS RESOURCES & ARII & 2017 & 2.27 \\
\hline & & 2018 & 0.95 \\
\hline
\end{tabular}

6. Perangkingan

Setelah didapatkan nilai rangking untuk setiap perusahaan, maka dapat diurutkan perusahaan berdasarkan nilai 
rangking tertinggi. Untuk memperjelas perusahaan tersebut memperoleh laba atau rugi, maka perlu ditambahkan informasi laba/rugi untuk setiap perusahaan. Karena belum tentu perusahaan yang mempunyai nilai rangking yang tinggi, memperoleh laba pada saat periode tersebut. Untuk lebih lengkapnya, berikut merupakan urutan perusahaan berdasarkan nilai rangking tertinggi :

Tabel 8. Urutan Perangkingan

\begin{tabular}{|c|c|c|c|c|}
\hline No & Nama Perusahaan & Inisial & Tahun & Nilai Ranking \\
\hline 1 & GARDA TUJUH BUANA & GTBO & 2018 & 179.43 \\
\hline 2 & PERDANA KARYA PERKASA & PKPK & 2018 & 10.32 \\
\hline 3 & GOLDEN EAGLE ENERGY TBK & SMMT & 2018 & 6.13 \\
\hline 4 & GOLDEN ENERGY MINES & GEMS & 2017 & 4.75 \\
\hline 5 & HARUM ENERGY & HRUM & 2017 & 4.72 \\
\hline 6 & GOLDEN EAGLE ENERGY TBK & SMMT & 2016 & 4.69 \\
\hline 7 & GOLDEN ENERGY MINES & GEMS & 2018 & 4.55 \\
\hline 8 & GOLDEN ENERGY MINES & GEMS & 2016 & 4.52 \\
\hline 9 & HARUM ENERGY & HRUM & 2016 & 4.43 \\
\hline 10 & PETROSEA & PTRO & 2018 & 4.18 \\
\hline 11 & ADARO ENERGY TBK & ADRO & 2017 & 4.16 \\
\hline 12 & ALFA ENERGI INVESTAMA & FIRE & 2018 & 4.08 \\
\hline 13 & ADARO ENERGY TBK & ADRO & 2016 & 4.03 \\
\hline 14 & PETROSEA & PTRO & 2016 & 4 \\
\hline 15 & ADARO ENERGY TBK & ADRO & 2018 & 3.99 \\
\hline 16 & RESOURCE ALAM INDONESIA & KKGI & 2017 & 3.83 \\
\hline 17 & MITRABARA ADIPERDANA TBK & MBAP & 2017 & 3.82 \\
\hline 18 & TOBA BARA SEJAHTERA TBK & TOBA & 2017 & 3.82 \\
\hline 19 & MITRABARA ADIPERDANA TBK & MBAP & 2016 & 3.76 \\
\hline 20 & RESOURCE ALAM INDONESIA & KKGI & 2016 & 3.76 \\
\hline 21 & HARUM ENERGY & HRUM & 2018 & 3.75 \\
\hline 22 & PETROSEA & PTRO & 2017 & 3.71 \\
\hline 23 & TOBA BARA SEJAHTERA TBK & TOBA & 2016 & 3.7 \\
\hline 24 & SAMINDO RESOURCE TBK & MYOH & 2016 & 3.66 \\
\hline 25 & SAMINDO RESOURCE TBK & MYOH & 2018 & 3.65 \\
\hline 26 & BAYAN RESOURCE & BYAN & 2018 & 3.62 \\
\hline 27 & RESOURCE ALAM INDONESIA & KKGI & 2018 & 3.57 \\
\hline 28 & TOBA BARA SEJAHTERA TBK & TOBA & 2018 & 3.49 \\
\hline 29 & DELTA DUNIA MAKMUR & DOID & 2018 & 3.46 \\
\hline 30 & MITRABARA ADIPERDANA TBK & MBAP & 2018 & 3.45 \\
\hline 31 & SAMINDO RESOURCE TBK & MYOH & 2017 & 3.43 \\
\hline 32 & TAMBANG BATUBARA BUKIT ASAM & PTBA & 2018 & 3.4 \\
\hline 33 & BAYAN RESOURCE & BYAN & 2017 & 3.38 \\
\hline 34 & DELTA DUNIA MAKMUR & DOID & 2016 & 3.35 \\
\hline 35 & PERDANA KARYA PERKASA & PKPK & 2017 & 3.34 \\
\hline 36 & GOLDEN EAGLE ENERGY TBK & SMMT & 2017 & 3.32 \\
\hline 37 & TAMBANG BATUBARA BUKIT ASAM & PTBA & 2017 & 3.32 \\
\hline 38 & DELTA DUNIA MAKMUR & DOID & 2017 & 3.28 \\
\hline 39 & ALFA ENERGI INVESTAMA & FIRE & 2016 & 3.22 \\
\hline 40 & TAMBANG BATUBARA BUKIT ASAM & PTBA & 2016 & 3.17 \\
\hline 41 & BAYAN RESOURCE & BYAN & 2016 & 3.13 \\
\hline 42 & ALFA ENERGI INVESTAMA & FIRE & 2017 & 3.13 \\
\hline 43 & GARDA TUJUH BUANA & GTBO & 2017 & 3.03 \\
\hline 44 & BARA JAYA INTERNASIONALTBK & ATPK & 2017 & 2.97 \\
\hline 45 & BUMI RESOURCE & BUMI & 2018 & 2.93 \\
\hline 46 & BUMI RESOURCE & BUMI & 2016 & 2.81 \\
\hline
\end{tabular}




\begin{tabular}{llccc}
\hline No & \multicolumn{1}{c}{ Nama Perusahaan } & Inisial & Tahun & Nilai Ranking \\
\hline 47 & BUMI RESOURCE & BUMI & 2017 & 2.54 \\
48 & PERDANA KARYA PERKASA & PKPK & 2016 & 2.51 \\
49 & ATLAS RESOURCES & ARII & 2017 & 2.27 \\
50 & ATLAS RESOURCES & ARII & 2016 & 2.15 \\
51 & BARA JAYA INTERNASIONALTBK & ATPK & 2018 & 2.14 \\
52 & GARDA TUJUH BUANA & GTBO & 2016 & 1.79 \\
53 & ATLAS RESOURCES & ARII & 2018 & 0.95 \\
54 & BARA JAYA INTERNASIONALTBK & ATPK & 2016 & 0.86 \\
\hline
\end{tabular}

Dari hasil profile matching didapatkan nilai PT. Garda Tujuh Buana untuk tahun 2018 mendapatkan nilai tertinggi dengan nilai 179,43 . Hasil yang sangat mencolok ini dikarenakan piutang PT. Garda Tujuh Buana untuk tahun 2018 sangat rendah dan mempengaruhi hasil secara keseluruhan.

\section{KESIMPULAN}

\section{Kesimpulan}

Dalam penulisan skripsi ini dapat disimpulkan beberapa hal yang diperlukan untuk menganalisis laporan keuangan perusahaan yang terdaftar di Bursa Efek Indonesia yang bergerak dibidang batu bara untuk laporan keuangan tahun 2016 - 2018. Peneliti menggunakan metode analisis rasio dalam mengolah laporan keuangan tersebut, kemudian menggunakan metode Profile Matching untuk mengolah kembali hasil analisis rasio. Dalam penelitian tersebut, peneliti menarik kesimpulan sebagai berikut:

1. Analisa laporan keuangan menggunakan metode analisis rasio dilakukan untk menganaisa laporan keuangan tahun 2016 - 2018, laporan tersebut akan menghasilkan rasio keuangan.

2. Hasil dari rasio keuangan perusahaan yang didapatkan menggunakan analisis rasio dilakukan pengolahan kembali menggunakan metode Profile Matching, dari pengolahan data menggunakan metode Profile Matching didapatkan urutan rangking perusahaan yang dapat digunakan investor sebagai salah satu bahan pertimbangan untuk membeli saham.

\section{Saran}

Setelah penulis menyelesaikan tahap akhir dari penelitian ini, penulis menyadari masih banyak kekurangankekurangan yang mesti diperbaiki dan dipenuhi, antara lain :

1. Bagi perusahaan, dari hasil penelitian yang dilakukan perusahaan dapat memperbaiki kinerja keuangannya dengan penelitian ini sebagai salah satu bahan pertimbangan.

2. Bagi investor, dari hasil penelitian yang dilakukan investor dapat menjadikannya sebagai salah satu bahan pertimbangan dalam 
melakukan pembelian dan/atau penjualan saham.

3. Bagi peneliti selanjutnya disarankan untuk melakukan penelitian yang lebih kompleks.

\section{DAFTAR REFERENSI}

Babalola, Y. A. and Abiola F.R. 2013. Financial Ratio Analysis of Firms: A Tool for Decision Making. International Journal of Management Sciences. 1(4). pp. 132-137.

Dewi S. 2013. Analisis Laporan Keuangan Untuk Menilai Kinerja Keuangan Pada PT. Bank Rakyat Indonesia (PERSERO) Tbk. Skripsi. Surakarta: Fakultas Ekonomi dan Bisnis Universitas Muhammadiyah Surakarta.

Eniyati, S. 2011. Perancangan Sistem Pendukung Pengambilan Keputusan untuk Penerimaan Beasiswa dengan Metode SAW (Simple Additive Weighting). Jurnal Teknologi Informasi DINAMIK. 16(2). pp. 171-176.

Harahap, S. S. 2009. Analisa Kritis Atas Laporan Keuangan. Jakarta: PT. Raja Grafindo Persada.

Ikatan Akuntansi Indonesia. 2018. Standar Akuntansi Keuangan. Jakarta: Salemba Empat.

Irawan, M. T. 2016, Penerapan Profile Matching untuk Pencarian Siswa SMP Penerima Beasiswa Miskin
Dan Berprestasi.

Kashmir. 2010. Analisis Laporan Keuangan. Jakarta: PT. Raja Grafindo Persada.

Masitoh, Suhendar, A. 2016. Penerapan Metode Profile Matching Dalam Pengembangan Aplikasi ECommerce Pada Penjualan Barang Elektronik. Jurnal Sistem Informasi. pp. 19-24.

Munawir. 2010. Analisis Laporan Keuangan. $4^{\text {th }}$ ed. Yogyakarta: Liberty.

Natali, D., Samben, R., dan Musviyanti. Analisis Rasio Likuiditas, Rasio Solvabilitas Dan Rasio Profitabilitas Untuk Mengukur Kinerja Keuangan Pada PT. KUD Kopta Unit Tambang Periode 2009-2010. Samarinda.

Putra, E. R. 2016. Penerapan Algoritma Rough Set Dan Metode Analisis Rasio Dalam Menganalisa Laporan Keuangan (Studi Kasus Bursa Efek Indonesia Cabang UPI-YPTK).

Putra, E. R. 2017. Penerapan metode profile matching dalam menganalisa laporan keuangan perusahaan sektor makanan dan minuman yang terdaftar di Bursa Efek Indonesia.

Seradi, A. 2016. Penerapan Metode Profile Matching Untuk Menentukan Kelayakan Pemberian Kredit Pada Pnpm Mandiri Kota Banjarmasin. Jurnal Teknologi Informasi. 